\title{
DETERMINATION OF UNIAXIAL COMPRESSIVE STRENGTH OF LIMESTONE
}

\section{ODREĐIVANJE JEDNOOSNE TLAČNE ČVRSTOĆE VAPNENACA}

\author{
Doris Vračević*, Sanja Dugonjić Jovančević \\ Josip Peranić́, Marko Hodanić ${ }^{*}$
}

\begin{abstract}
The most used parameter in rock engineering practice is the Uniaxial Compressive Strength (UCS). It is often estimated on the field or trough Index-to-strength conversion factors proposed by various researchers for a specific rock type. The research presented in the paper involved field estimation of Uniaxial Compressive Strength using Schmidt rebound hammer and Point Load laboratory testing on limestone rock samples. The results of the estimated UCS were compared to the Uniaxial Compression Strength laboratory testing results on limestone specimens taken from the same location, in order to compare corresponding UCS of limestone rocks. These results can contribute to better estimation of the local design parameters, when direct determination of the UCS in the laboratory is not possible, rather than adopting the values from around the world case studies.
\end{abstract}

Key words: limestone, Uniaxial Compressive Strength, Point Load Test, Schmidt rebound hammer, field identification

\section{Sažetak}

Najčešće korišten parametar u stijenskom inženjerstvu je jednoosna tlačna čvrstoća (UCS). Često se procjenjuje na terenu ili pomoću korelacija s indeksom čvrstoće u točki predloženih od strane različitih istraživača za određen tip stijene. Istraživanja prikazana u radu uključuju terenska ispitivanja jednoosne tlačne čvrstoće Schmidtovim čekićem i laboratorijskog ispitivanja indeksa čvrstoće opterećenjem u točki na uzorcima vapnenačkih stijena. Rezultati procijenjenih UCSa uspoređeni su s laboratorijskim ispitivanjem jednoosne tlačne čvrstoće na uzorcima

\footnotetext{
* Sveučilište u Rijeci, Građevinski fakultet, Radmile Matejčić 3, 51000 Rijeka E-mail: dvracevic@student.uniri.hr; marko.hodanic@gradjevinar.hr; \{sanja.dugonjic.jovancevic,josip.peranic\}@uniri.hr
} 
vapnenaca, uzetih sa iste lokacije, kako bi se usporedili rezultati za odgovarajući UCS vapnenačkih stijena. Ovi rezultati mogu pridonijeti boljoj procjeni lokalnih projektnih parametara kada određivanje točne vrijednosti UCS u laboratoriju nije moguće, no ne i usvajanju vrijednosti dobivenih analizom slučajeva iz ostatka svijeta.

Ključne riječi: vapnenac, jednoosna tlačna čvrstoća, ispitivanje čvrstoće u točki, Schmidtov čekić, terenska identifikacija

\section{Introduction}

Uniaxial Compressive Strength (UCS) defines mechanical strength of the intact rock material and it is one of the most used parameters in rock engineering. In the laboratory, it is determined by uniaxial compression on circular cylinder specimens according to standardized test procedures [1,2]. However, as sometimes cylindrical intact rock specimens are inaccessible or difficult to obtain and examine, simple field tests and correlations are often used instead. Many researchers developed relations of the field identification by geological hammer or the Point Load Strength Index $\left(\mathrm{I}_{\mathrm{s} 50}\right)$ obtained from Point Load Test (PLT) with the UCS value (Table 1).

Table 1. Relations for the UCS estimation through various test methods

\begin{tabular}{|l|c|l|}
\hline \multicolumn{1}{|c|}{ Reference } & \multicolumn{1}{c|}{ Correlation } & \multicolumn{1}{c|}{ Rock type } \\
\hline \multicolumn{1}{|c|}{ Correlation between Schmidt hammer rebound number and UCS } \\
\hline $\begin{array}{l}\text { Cargill and Shakoor } \\
\text { (1990) [16] }\end{array}$ & $U C S=18.17 e^{\left(0,02 \rho R_{n}\right)}$ & carbonates \\
\hline Sachpazis 1990, [17] & $U C S=4.29 R_{n}-67.52$ & carbonates \\
\hline $\begin{array}{l}\text { Yurdakul et al. 2011, } \\
\text { [18] }\end{array}$ & $U C S=0.0682 R_{n}+57.973$ & carbonates \\
\hline Nazir et al. 2013, [19] & $U C S=12.83 e^{\left(0.0487 R_{n}\right)}$ & limestone \\
\hline \multicolumn{1}{|c|}{ Correlations between $U C S$ and Is $(50)$} & \\
\hline Romana 1999 [20] & $U C S=(14.5 \div 27) I s_{50}$ & limestone \\
\hline $\begin{array}{l}\text { Tsiambaos and } \\
\text { Sabatakakis 2004, [21] }\end{array}$ & $U C S=7.3 I s_{50} 1.71$ & $\begin{array}{l}\text { limestone, } \\
\text { sandstone, marl }\end{array}$ \\
\hline Tahir et al. 2011 [22] & $U C S=21.691 I s_{50}$ & limestone \\
\hline
\end{tabular}

It is evident from the overview of the existing literature that the existing data related to limestone and carbonate rocks are few in general. On the other hand, there are frequent rockfalls on cuts along the roads, causing 
problems and demanding certain stabilization measures, as well as deep seated landslides in the area of carbonate-flysch geological contact [3]. The focus of the present studies in the wider area of the testing locations (Vinodol and Rječina River Valley) are the instability phenomena [4-9] and some flysch rock mass properties closely related to landslide initiation, such as weathering in relation with the strength reduction $[10,11]$ and hydromechanical properties related to precipitation amounts [12, 13]. However, UCS values of limestone in the coastal area of Croatia are mostly parts of the geotechnical designs, related to rock mass engineering, unavailable for the public, and in the interest of this research. Simple methods used to assess the UCS values from tables, diagrams or relations with some index testing, are however simple, reliable for simple geotechnical constructions and early design phases, and any new insight in that direction is of big interest. Several different methods for determination of UCS of limestone rock are presented in this paper [14, 15], as shown in Table 2 . The aim of this study was to obtain the UCS values of the limestone rock mass, compare the obtained values and possible correlation factors trough different testing methods, determine the Young module and the Poisson coefficient from the stress deformation curve, and to get to some conclusions about the possible testing procedure errors.

Table 2. Testing methods used for (UCS) determination

\begin{tabular}{lll}
\multicolumn{1}{c}{ Investigation type } & \multicolumn{1}{c}{ Test method } & \multicolumn{1}{c}{ Test type } \\
\hline \multirow{2}{*}{ Field investigation } & $\begin{array}{l}\text { Field assessment using } \\
\text { geological hammer }\end{array}$ & $\begin{array}{l}\text { Indirect subjective } \\
\text { estimation }\end{array}$ \\
\cline { 2 - 3 } Laboratory investigation & Schmidt Rebound Hardness & $\begin{array}{l}\text { Indirect objective } \\
\text { estimation }\end{array}$ \\
\hline & $\begin{array}{l}\text { Point Load Test } \\
\text { Uniaxial compression } \\
\text { testing }\end{array}$ & $\begin{array}{l}\text { Indirect index to } \\
\text { strength correlation }\end{array}$ \\
\hline
\end{tabular}

\section{Research area}

\subsection{Research locations}

Field rock strength testing was carried out on the slope of the local roads in the Križišće settlement, located in the Vinodol Valley (Vinodol), and along the road passing through the foot of an ancient dormant landslide in the Rječina River Valley, located in the western part of the Republic of Croatia, in Primorje-Gorski kotar County. The testing locations were selected as a part of the research area within the University of Rijeka scientific project Analysis of the rock mass and instability phenomena along 
the karst-flysch contacts. One of the aims of this project was to determine UCS values and deformability of limestone rock in the research area that includes Gray Istria, Rječina River Valley and Vinodol Valley.

The research area is a part of a dominant morphostructural unit belonging to the High Karst of the External Dinarides, which covers the area from Ilirska Bistrica (Slovenia) in the NW to Novi Vinodolski on the Adriatic coast (Croatia) in the SE. The unit is of a $100 \mathrm{~km}$ long narrow and elongated shape, formed along the tectonic contact between carbonate and siliciclastic rocks [23]. Paleogene flysch rock mass is located at the bottom of the valleys, mostly covered by Quaternary superficial deposits, i.e. products of physical and chemical weathering of carbonate and siliciclastic rocks [8]. Karstified carbonate rocks (older Paleogene and the Upper Cretaceous) are visible at the top of the slopes (Figure 1). The wedge of the syncline is characterized by a fault contact between the carbonate and flysch deposits.

\subsection{Materials}

Tests were performed on limestone rock in the Vinodol Valley (Figure 1a) and in the Rječina River Valley (Figure 1b). The limestone at the test site 1 (TS 1) shows a superficially more weathered rock mass of light brown to moderate yellowish brown colour. The limestone at the test site 2 (TS 2) shows a rock mass of pinkish-grey to greyish orange colour according to the Münsell scale for rock mass characterization. The rock mass at TS 2 is, however, interrupted by numerous discontinuities. The limestone at the test site 3 (TS 3 ) shows hard and compact rock blocks of light grey colour, containing number of barely visible micro cracks, established during specimen preparation. When selecting the block samples for UCS laboratory testings, it was important to make sure there are no significant discontinuities on the selected block, and that the sample is appropriate for obtaining more specimens if possible (at least 5) and easy to transport.
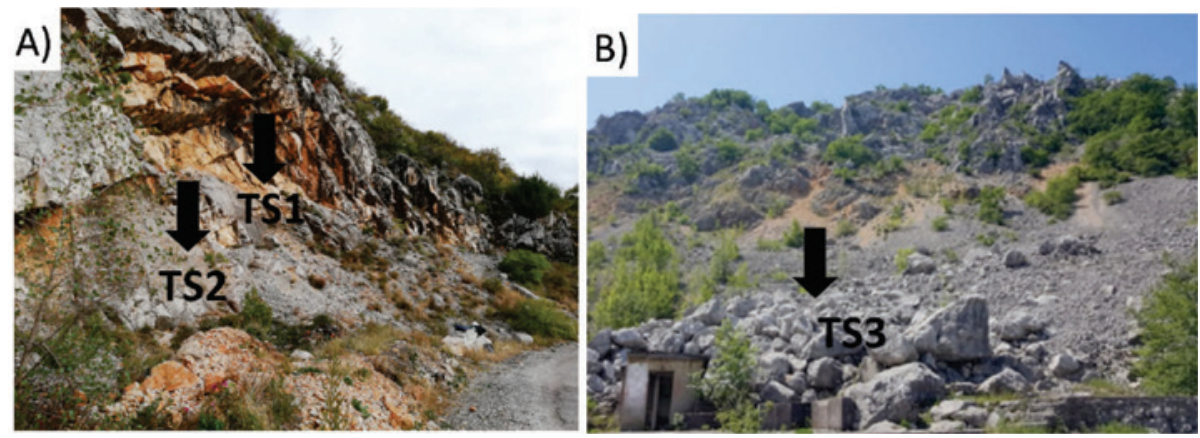

Figure 1. Location of the limestone test sites: a) Vinodol Valley: TS1 and TS2; b) Rječina River Valley: TS3 


\section{Methods for determination of limestone strength}

Field testing of limestone was carried out using two most common methods, Schmidt and geological hammer, while laboratory testing was carried out using the PLT device and the FORM + TESTs ALPHA 1-2000s machine (Table 2). Some of the procedures show the indirect UCS value estimation, while direct measurement of the UCS is possible only through the uniaxial compression testing.

\subsection{Schmidt rebound hardness}

The Schmidt rebound hardness value $\left(\mathrm{R}_{\mathrm{n}}\right)$ is maybe the most frequently used index in rock mechanics practice for UCS estimation because it is simple, portable, affordable and non-destructive. Schmidt hammer is a device used to estimate rock mass strength in situ. The main part of the device is a steel impact clip, which, after being charged into the rock, is bounced back and returns to a certain position. The shock value after the hit, considering its starting position before the hit, is the measure of the test material rebound hardness. Samples must be tested on a rigid surface so that no movement of the rock is possible. The advantage of this device is that it can be used in the field as well as laboratory, and a larger number of tests can be reported in a very short time. However, the obtained results refer only to up to $30 \mathrm{~mm}$ of the surface layer. The testing procedure on limestone rock was performed using L type hammer of impact energy $0.735 \mathrm{Nm}$.

For TS 1 and TS 2 (Figure 1a), the Schmidt rebound hardness testing was performed on the slope face, a detached block at the foot of the slope, and another block sample transported to the laboratory. The testing was repeated in the described way to see the impact of block detachment on the results. At the TS 3 test site, the rebound hardness was determined on detached blocks at the slope foot. To avoid frictional sliding of the plunger tip, hammer impact direction was perpendicular to the tested surface. 20 values, as recommended by ISRM suggested method [1], were recorded on a sample at different points, and the upper 10 values were averaged to calculate the rebound hardness $\left(R_{n}\right)$. Using $R_{n}$ and the corresponding unit weight for the limestone rock obtained in the uniaxial compression testing in the laboratory $\left(\gamma=27 \mathrm{kN} / \mathrm{m}^{3}\right.$ for TS 1 and TS $2 ; \gamma=26.8 \mathrm{kN} / \mathrm{m} 3$ for TS 3$)$, UCS values were determined and presented on the diagram published in [24].

\subsection{UCS Field estimation using geological hammer}

The Uniaxial Compressive Strength boundary value, which separates the soil and the rock, is $1 \mathrm{MPa}$. Field identification to assess UCS is developed, both for soil and rock identification, and Table 3 presents only the part concerning rock materials. UCS estimation can be performed by 
pressing the nail, a pocket knife (for soft rocks) or blowing the rock with the geological hammer (Table 3). For the testing locations, shown in Figure 1 , standard geological hammer was used to estimate UCS values.

Table 3. Estimation of UCS by simple field tests [25]

\begin{tabular}{|c|l|l|c|}
\hline Grade & \multicolumn{1}{|c|}{ Description } & \multicolumn{1}{|c|}{ Field identification } & UCS(MPa) \\
\hline R0 & $\begin{array}{l}\text { Extremely } \\
\text { weak rock }\end{array}$ & Indented with a thumbnail & $0.25-0.10$ \\
\hline Rery weak & $\begin{array}{l}\text { Crumbles under firm blows with the } \\
\text { point of geological hammer, can be } \\
\text { peeled with a pocket knife }\end{array}$ & $1.0-5.0$ \\
\hline R3 & $\begin{array}{l}\text { Medium } \\
\text { strong rock }\end{array}$ & $\begin{array}{l}\text { Can be peeled with a pocket knife with } \\
\text { difficulty, shallow indentations made } \\
\text { with a firm blow with the point of } \\
\text { geological hammer }\end{array}$ & $5.0-25$ \\
\hline R4 & $\begin{array}{l}\text { Strong rock } \\
\text { with a single firm blow of geological } \\
\text { hammer }\end{array}$ & $\begin{array}{l}\text { Specimen requires more than one blow } \\
\text { of geological hammer to fracture it }\end{array}$ & $25-50$ \\
\hline R5 & $\begin{array}{l}\text { Very strong } \\
\text { rock }\end{array}$ & $\begin{array}{l}\text { Specimen requires many blows of } \\
\text { geological hammer to fracture it }\end{array}$ & $100-250$ \\
\hline R6 & $\begin{array}{l}\text { Extremely } \\
\text { strong rock }\end{array}$ & $\begin{array}{l}\text { Specimen can only be chipped with a } \\
\text { geological hammer }\end{array}$ & $>250$ \\
\hline
\end{tabular}

\subsection{Point Load Test}

The Point Load Test (PLT) has widely been used around the world for more than three decades following the early work by Deere and Miller (1966) [26]. It can also be used to make correlation with UCS and tensile strength. The device consists of a loading part, including two conical spikes (at $60^{\circ}$ ), and a force gauging device at which the break occurs (Figure 2). The test procedure is standardized by both ASTM [27] and ISRM [28]. In the present research, the PLT was performed in accordance with the ISRM standardized procedure for irregular sample testing. During the sample collection and prior testing, it was necessary to check whether the sample dimensions are satisfactory. The size range of irregular samples tested in this case should be $50 \mathrm{~mm}$ to $+/-85 \mathrm{~mm}$ and most preferably $50 \mathrm{~mm}$. The distance L (sample length) from the end of the sample to the contact point should be at least 0.5 W (sample height). Afterwards, rock samples are pressed between conical steel plates that transfer the load onto the sample through conical spikes. It 
is important to properly centre the sample, so that it does not fall out during the loading. The failure occurs in the period of 10 to 60 seconds. At that point, the force under which the breakdown occurred and the sample dimensions are recorded. In some cases, irregular fractures may occur due to sample inhomogeneity, and tests are rejected according to the standard procedure. According the ISRM procedure, when calculating the UCS value from the 10 or more valid tests, the smallest and greatest force records are not taken into account, and for the remaining, the average strength value is calculated. 11, 12 and 10 valid tests were performed on TS 1 , TS 2 and TS 3 respectively (Table 4). In order to see the error due to failure surface assessment, the UCS estimation for this research was carried out by double data processing (direct measurement of the average failure surface length and height, and by digital processing of the exact failure surface by scanning the failure surface and digital area calculation using AutoCAD.).

The uncorrected Point Load Strength Index $\mathrm{I}_{\mathrm{S}}$ of limestone samples was determined using the following equation:

$$
I_{S}=\frac{P}{D_{e}^{2}}[M P a]
$$

where:

$\mathrm{P}$ - is failure load $[\mathrm{N}]$

$\mathrm{D}_{\mathrm{e}}$ - equivalent core diameter $[\mathrm{mm}]$, given by the following equations:

$\mathrm{D}_{\mathrm{e}}{ }^{2}=\mathrm{D}^{2}\left[\mathrm{~mm}^{2}\right]$ - for cores

$\mathrm{D}_{\mathrm{e}}{ }^{2}=\frac{4 * A}{\pi}\left[\mathrm{mm}^{2}\right]-$ for axial test (where is the minimum cross-sectional area of plane through the platen contact points, $\mathrm{A}=\mathrm{W} \cdot \mathrm{D}$, or the digitalized failure surface).

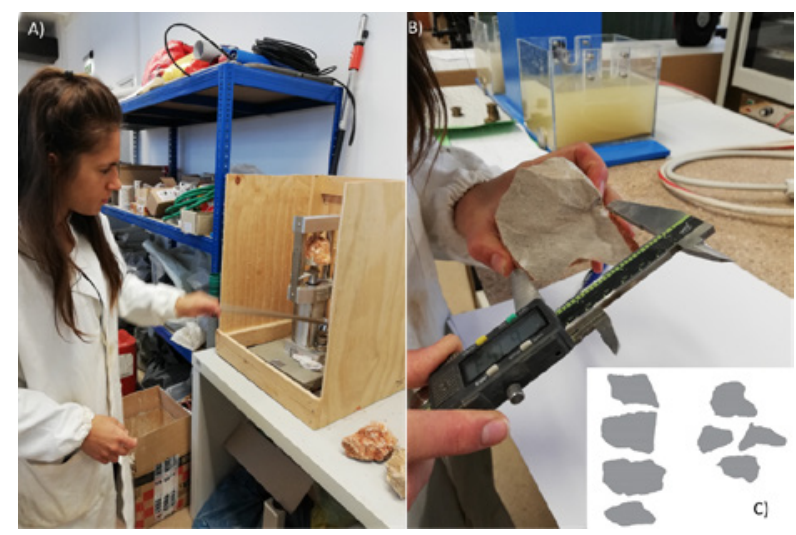

Figure 2. PLT device in the geotechnical laboratory at the University of Rijeka: a) load increase, b) determination of the average failure surface dimensions, c) digitalized exact failure surface 
If the test is carried out on samples whose effective diameters are not $50 \mathrm{~mm}$, correction factor $\mathrm{F}$ is introduced according to the formula:

$$
F=\left(\frac{D_{e}}{50}\right)^{0,45}
$$

\subsection{Uniaxial Compression Strength laboratory testing}

The uniaxial compression test is designed to measure the axial compressive strength of the rock on a regular geometric pattern and is used to classify the strength and characterization of the intact rock. The test is performed on samples of cylindrical shape, recommended height/diameter ratio between 2.5-3 [25]. The uniaxial compression was performed according to ISRM standard using FORM+TESTs ALPHA 1-2000s uniaxial compression testing machine at the Geotechnical Laboratory of the Faculty of Civil Engineering in Rijeka. In order to preserve the natural moisture, the samples should not be older than 30 days (in this case 3 weeks). Block samples taken on the field are delivered to the laboratory, where specimens were drilled, sawed and finally grinded in order to meet dimensions and shape tolerance limits according to the ASTM standards [29]. Due to barely visible micro cracks, it was hard to obtain the required specimens, especially for TS 3. During some stages of specimen preparation, the failure occurred regularly, and in the end, five specimens were tested. However, testing of dimension and shape tolerance have shown that these requirements are high. UCS testing procedure imposes that deformation and loads are applied continuously in the way that failure occurs within 5 to 10 minutes. Both ASTM and ISRM standards for the determination of UCS of intact rocks define the stress gain in the range of 0.5 to $1 \mathrm{MPa} / \mathrm{s}$.

Testing of Vinodol and Rječina Valley limestone samples was carried out following the two procedures:

i. deformation controlled test - a predetermined rate of deformation gain in time $(0.05 \mathrm{~mm} / \mathrm{min})$, measuring the stress (force)

ii. stress controlled test - a predetermined stress-boost rate $(0.5 \mathrm{MPa} / \mathrm{s})$, measuring axial and radial deformation in time.

Sample height shortening $(\Delta \mathrm{L})$ was calculated as the mean value of measurements using three LVDTs (axial displacement measures). The LVDT measure changes in the upper platen distance, rather than changing the sample height. Radial deformation, i.e. change in sample diameter $(\Delta D)$, is measured using one LVDT placed at mid-height of the specimens (Figure 3 ). Axial $\left(\varepsilon_{a x}\right)$ and radial deformation $\left(\varepsilon_{r}\right)$ are defined by expressions ( 3 and 4$)$ :

$$
\varepsilon_{a x}=\frac{\Delta L}{L_{0}}
$$




$$
\varepsilon_{r}=\frac{\Delta D}{D_{0}}
$$

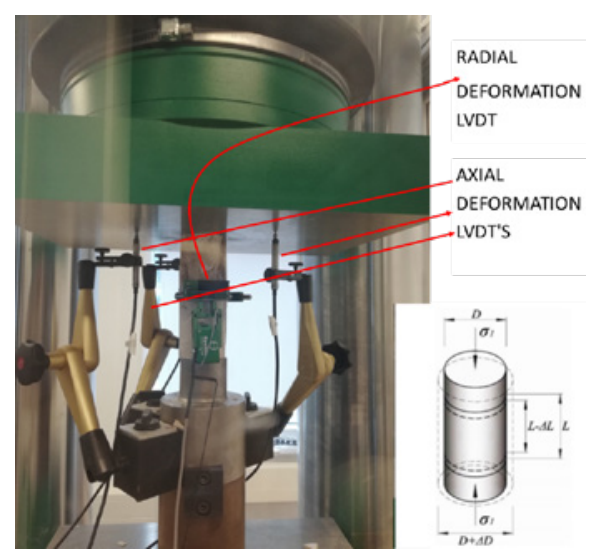

Figure 3. UCS testing: radial and axial displacement measurements and specimen deformation scheme

The stress $(\sigma)$ is calculated from the force relationship and the initial surface of the sample using the expression:

$$
\sigma=\frac{F}{A_{0}}
$$

The elasticity modulus $(E)$ and the Poisson coefficient $(v)$ for all three sets are determined from the linear part of the stress-strain curve.

\section{The results}

\subsection{Schmidt hammer rebound hardness}

The results of the Schmidt hammer testing on the detached block, slope face and sample delivered to the laboratory are shown in Figure 4, where red lines show each performed test, and blue lines the unit weight used in calculation. Considering the different weathering grades, estimated UCS values vary from 59.5 to $65 \mathrm{MPa}$ for TS 1, 78.5-105 MPa for TS 2 and 51 to $110 \mathrm{MPa}$ for TS 3. Triple testing on TS 1 and TS 2 has shown that there is no considerable difference in rebound hardness value if performing the test on the detached block or at the slope face. 

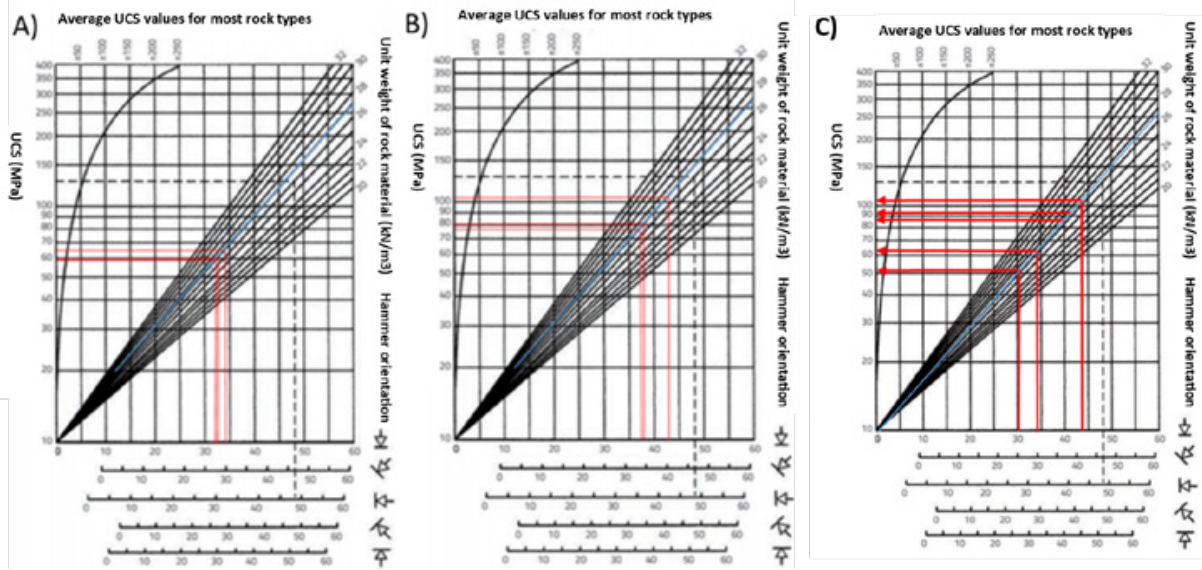

Figure 4. UCS estimated from the Schmidt hammer rebound hardness and unit weight of the rock material: a) TS 1, b) TS 2, c) TS 3

\subsection{Field estimation}

Field estimation of the rock strength using geological hammer at all locations showed that more than one blow of geological hammer is needed to break the rock. According to field identification (Table 3) the estimated UCS is $50-100 \mathrm{MPa}$, and the examined limestone can be classified as strong rock.

\subsection{Point Load Test}

In order to show the influence of the failure surface area calculated from the average height and width dimensions, in relation to the digital calculation of its actual value, the PLT testing results have been made for double data processing of the failure surface area. The results for manually measured and estimated failure surface show similar values as for digitally processed surface Table 4 shows the results of $\mathrm{I}_{\mathrm{s}(50)}$ from the performed PLT testing for digitally processed failure surface area. The average value of the $\mathrm{I}_{\mathrm{s}(50)}$ was calculated by omitting the two highest and lowest values from the testing results, and the mean of the remaining values for three test sites is $2.8,3.2$ and 2.06 respectively. 
Table 4. The estimation of $I_{S(50)}$ values from the PLT testing

\begin{tabular}{|c|c|c|c|c|c|c|c|}
\hline $\mathrm{A}\left(\mathrm{mm}^{2}\right)$ & $\mathrm{P}(\mathrm{N})$ & $\mathrm{D}_{\mathrm{e}}^{2}\left(\mathrm{~mm}^{2}\right)$ & $\mathrm{D}_{\mathrm{e}}(\mathrm{mm})$ & $\mathrm{I}_{\mathrm{s}}(\mathrm{MPa})$ & $\mathrm{F}$ & $\mathrm{I}_{\mathrm{S}(50)}$ & \\
\hline 2300 & 10090 & 2928.45 & 54.12 & 3.45 & 1.04 & 3.57 & \multirow{11}{*}{ TS 1} \\
\hline 4300 & 13240 & 5474.93 & 73.99 & 2.42 & 1.19 & 2.88 & \\
\hline 2400 & 9800 & 3055.77 & 55.28 & 3.21 & 1.05 & 3.36 & \\
\hline 3700 & 13720 & 4710.99 & 68.64 & 2.91 & 1.15 & 3.36 & \\
\hline 4300 & 14220 & 5474.93 & 73.99 & 2.6 & 1.19 & 3.1 & \\
\hline 2500 & 7330 & 3183.1 & 56.42 & 2.3 & 1.06 & 2.43 & \\
\hline 4700 & 15380 & 5984.23 & 77.36 & 2.57 & 1.22 & 3.13 & \\
\hline 2800 & 6460 & 3565.07 & 59.71 & 1.81 & 1.08 & 1.96 & \\
\hline 4000 & 11960 & 5092.96 & 71.36 & 2.35 & 1.17 & 2.76 & \\
\hline 4700 & 2380 & 5984.23 & 77.36 & 0.4 & 1.22 & 0.48 & \\
\hline 6400 & 1000 & 8148.73 & 90.27 & 0.12 & 1.3 & 0.16 & \\
\hline 10400 & 20200 & 13241.69 & 115.07 & 1.53 & 1.46 & 2.22 & \multirow{12}{*}{ TS 2} \\
\hline 3300 & 8750 & 4201.69 & 64.82 & 2.08 & 1.12 & 2.34 & \\
\hline 2900 & 12310 & 3692.39 & 60.77 & 3.33 & 1.09 & 3.64 & \\
\hline 4300 & 2820 & 5474.93 & 73.99 & 0.52 & 1.19 & 0.61 & \\
\hline 4900 & 6960 & 6238.87 & 78.99 & 1.12 & 1.23 & 1.37 & \\
\hline 1800 & 7840 & 2291.83 & 47.87 & 3.42 & 0.98 & 3.35 & \\
\hline 3800 & 14020 & 4838.31 & 69.56 & 2.9 & 1.16 & 3.36 & \\
\hline 5700 & 16980 & 7257.47 & 85.19 & 2.34 & 1.27 & 2.97 & \\
\hline 5900 & 21760 & 7512.11 & 86.67 & 2.9 & 1.28 & 3.71 & \\
\hline 2800 & 12570 & 3565.07 & 59.71 & 3.53 & 1.08 & 3.82 & \\
\hline 2600 & 13500 & 3310.42 & 57.54 & 4.08 & 1.07 & 4.34 & \\
\hline 4600 & 18330 & 5856.9 & 76.53 & 3.13 & 1.21 & 3.79 & \\
\hline 2674 & 3580 & 3405.19 & 58.35 & 1.05 & 1.07 & 1.13 & \multirow{10}{*}{ TS 3} \\
\hline 3221 & 6000 & 4101.51 & 64.04 & 1.46 & 1.12 & 1.64 & \\
\hline 3175 & 9650 & 4042.54 & 63.58 & 2.39 & 1.11 & 2.66 & \\
\hline 2792 & 5210 & 3554.91 & 59.62 & 1.47 & 1.08 & 1.59 & \\
\hline 1484 & 8010 & 1889.12 & 43.46 & 4.24 & 0.94 & 3.98 & \\
\hline 1761 & 7910 & 2241.83 & 47.35 & 3.53 & 0.98 & 3.44 & \\
\hline 1845 & 3730 & 2349.63 & 48.47 & 1.59 & 0.99 & 1.57 & \\
\hline 2930 & 4310 & 3730.03 & 61.07 & 1.16 & 1.09 & 1.26 & \\
\hline 2497 & 4360 & 3179.27 & 56.39 & 1.37 & 1.06 & 1.45 & \\
\hline 2090 & 9530 & 2660.7 & 51.58 & 3.58 & 1.01 & 3.63 & \\
\hline
\end{tabular}




\subsection{Uniaxial compression testing}

Uniaxial compression test was performed on one specimen from TS 1 (TS 1A), two limestone specimens from TS 2 (TS 2A and TS 2B), and five samples form TS 3 (TS $3 \mathrm{~A}-\mathrm{E}$ ), shown on Figure 5 after failure. Figure 6 shows resulting stress-strain curves. Based on the presented results, it can be seen that the UCS of the superficially weathered limestone (TS 1A) is significantly smaller (46.22 MPa), than the UCS for other test site in Vinodol Valley (TS 2A and B - 90.37 and $105.49 \mathrm{MPa}$ ) with average elastic modulus $51.8 \mathrm{GPa}$, and the average Poisson coefficient 0.19.

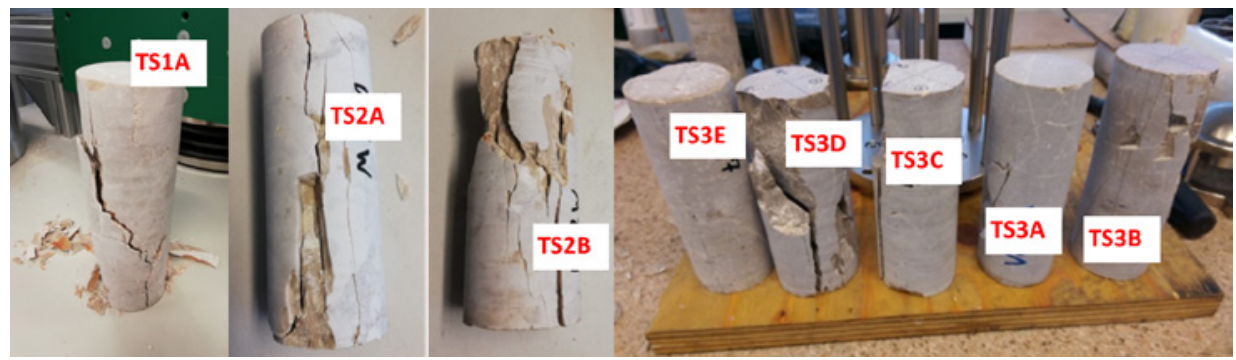

Figure 5. Tested specimens after failure in uniaxial compression

The UCS values obtained on the Rječina River Valley limestone ranged from 43.8 MPa for specimen TS 3E up to $100.3 \mathrm{MPa}$ for specimen TS 3C (Figure 6). It can also be seen that the specimens TS 3A and TS 3D had quite different UCS values although prepared from the same block sample. The average value of UCS, taking into account all five tests on TS 3, is 75.5 MPa.
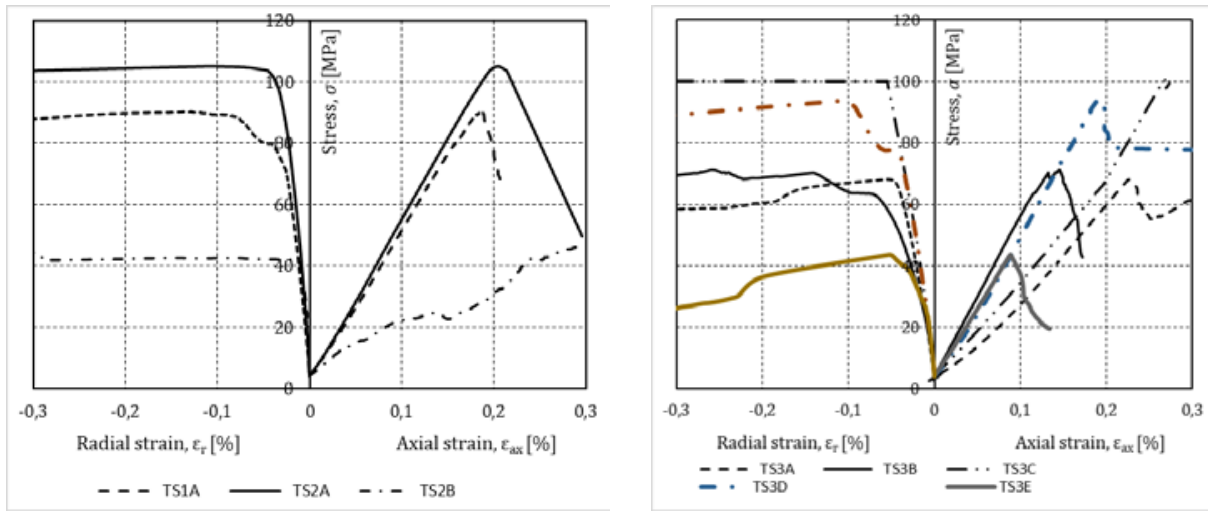

Figure 6. Stress-strain curves in uniaxial compression testing (Vinodol Valley samples - left; Rječina Valley samples - right) 
A negligible difference in the UCS value, determined in the uniaxial compression, was obtained by processing the data with constant specimen area and calculating the initial area change due to radial deformation of the specimen.

\section{Discussion}

The quality of the engineering solution depends primarily on the accuracy of the rock mass input parameters. The advantage of the Schmidt hammer is its simplicity for handling and rapid testing procedure, but the data reliability depends on the testing angle and personal experience during the test, and gives the results for the load applied to the area layer. Performing a PLT test is also less demanding and a simple testing procedure, but the level of personal experience when applying the loading speed and calculating the cross-sectional area can affect the obtained results. In the three decades since the earlier ISRM suggested method for conducting the Schmidt Hammer test was published, researchers have sought to establish correlations between the Schmidt Hammer rebound hardness number $\left(\mathrm{R}_{\mathrm{n}}\right)$ and the UCS for different rock types Aydin [30]. A critical review of the basic issues was conducted by Aydin and Basu [31], which considered the influence of hammer type, the direction of impact, specimen requirements, weathering, moisture content analysis procedures etc. The results of the UCS for limestone rock tested in this research using Schmidt rebound number have shown a very good accordance with the results from the uniaxial compression testing. Dobrilović at al. [32] emphasize the importance of the direction of the Schmidt Hammer rebound number testing in relation to the bedding planes in sedimentary rocks. They note that the testing should be performed perpendicular to bedding planes in order to obtain better correlation. In this research, the importance of the testing procedure was confirmed due to repeated testing on the detached block, slope face and the blocks in the laboratory. A certain difference was noted in the results on blocks tested in the laboratory and in situ, which implies the possible procedure error. Otherwise, the testing results on a larger block and slope face shows no significant difference.

Various authors have researched limestone rock mass to establish the Point Load Strength Index. Broch and Franklin [34] proposed for the limestone rock mass values of $\beta$ between 12 and 26. Galván et al. [35] have found that the mean value of $\beta$ for limestone type rocks from the Comunidad Valenciana is 13.6. Bieniawski [36] showed that the compressive strength is nearly 23 times $I_{S}$. Akram and Bakar [37] have also predicted UCS using relations with the $\mathrm{I}_{\mathrm{s}(50)}=3.59$ for Sakessar Nodular Limestone testing (the UCS was found to be correlated with $\mathrm{I}_{\mathrm{S}(50)}$ through a 
linear relationship, with a slope of 22.792 and the intercept of 13.295), and $\mathrm{I}_{\mathrm{S}(50)}=3.69$ for Sakessar Massive Limestone (UCS was found to be linear but with a slope of 11.076 and a zero intercept). Testing results of mechanical properties on three characteristic Cretaceous and Paleogene limestone blocks taken in Istria, Croatia [32] have presented $\mathrm{I}_{\mathrm{s}(50)}$ values from 2.3 to 3.96 , and corresponding UCS values 68.66 to $135.48 \mathrm{MPa}$. They lead to the conclusion that it is impossible to reach a unique correlation that would be applicable for every rock type. Analyzing the relations between the estimated UCS from the Point Load Index, it can be seen that for $50 \mathrm{~mm}$ core diameter index-to-strength conversion factor $(\beta)$ is approximately 16.5 for limestone on TS 1,31 for TS 2 and 36 for limestone in TS $3(\beta=28$ in average).

The correlation factors in index testing can vary depending not only on the rock type, but also the weathering grade, mineralogical composition, rock structure and also number of correlated results. It should be emphasized that due to inhomogeneity and anisotropy of intact rocks, it is important to examine multiple test specimens (at least 5). To accept a certain correlation, more samples than presented in this research should be tested. Therefore, additional testing is needed to improve the presented correlations for limestone rock in the investigated area.

\section{Conclusion}

Based on the previous researches on limestone rock mass presented in numerous references and the testing of limestone rock in this research, it can generally be concluded that results of all test vary significantly for the same rock mass type. Correlations with index factors are welcome for every new location. However, indirect test methods may be used to predict the compressive strength of rock, critically considering the variations in resulting values due to testing procedures, anisotropy, fractures, sample dimensions and other parameters, and including them in results interpretation. Using the correlations proposed in the literature, we should always have in mind the importance of the UCS in rock engineering projects.

Due to the strictly defined shape and dimensions of the specimens and the possibility of precise control through the testing procedure, the UCS testing in the laboratory is, of course, the most reliable way of determining the UCS value for rock material. The obtained results may depend on the specimen dimensions (size and slenderness). Another advantage of the uniaxial compression test is the ability to determine the characteristics of the rock deformability. On the other hand, index based tests can estimate the deformability module from empirical equations developed for different 
rock types and using different rock mass parameters. However, the required price and time for the testing makes such tests more demanding, and therefore, less performed compared to index tests presented in the paper.

Acknowledgments. This paper is a result of the work under the project Research Infrastructure Development at the University of Rijeka Campus (RC.2.2.06-0001) co-financed by the European Regional Development Fund (EFRR) and the Ministry of Science, Education and Sports of the Republic of Croatia, as well as the initial support of the University in Rijeka "Analysis of the rock mass and instability phenomena along the karst-flysch contacts "(18.06.2.1.01.).

\section{References}

[1] ISRM (1981) Suggested Methods for Rock Characterization Testing and Monitoring, Ed. E.T. Brown, Pergamon Press, Oxford.

[2] ASTM (1984) Standard Test Method for Unconfined Compressive Strength of Intact Rock Core Specimens, Soil and Rock, Building Stones, Annual Book of ASTM Standards 4.08., Philadelphia, Pennsylvania.

[3] Arbanas Ž., Mihalić Arbanas S., Vivoda M., Peranić J., Dugonjić Jovančević S., Jagodnik V. (2014) Identification, Monitoring and Simulation of Landslides in the Rječina River Valley, Croatia. Proceedings of the SATREPS workshop on landslide risk assessment technology (Sassa K., Khang Q.D. eds). International Consortium on Landslides, Kyoto, pp 200-213.

[4] Benac Č., Dugonjić S., Arbanas Ž., Oštrić M., Jurak V. (2009) The Origin Of Instability Phenomena Along The Karst-Flysch Contacts, ISRM International Symposium EUROCK 2009: Rock engineering in difficult ground conditions soft rock and karst, 29 - 31th October, Cavtat, Croatia, pp 757-761.

[5] Vivoda M., Benac Č., Žic E., Đomlija P., Dugonjić Jovančević S. (2012) Geohazard in the Rječina River Valley in Past and Present, Hrvatske vode, Journal for water economy, 20 (2012), 81, pp 105-116. (in Croatian)

[6] Arbanas Ž., Mihalić Arbanas S., Vivoda Prodan M., Peranić J., Sečanj M., Bernat Gazibara S., Krkač M. (2017) Preliminary Investigations and Numerical Simulations of a Landslide Reactivation. In: Mikos M., Tiwari B., Yin Y., Sassa K. (eds) Advancing Culture of Living with Landslides. WLF 2017. Springer, Cham

[7] Đomlija P., Bernat S., Mihalić Arbanas S., Benac Č. (2014) Landslide Inventory in the Area of Dubračina River Basin (Croatia), Landslide Science for a Safer Geoenvironment, Volume 2: Methods of Landslide Studies (Sassa K., Canuti P., Yin Y. eds). Switzerland: Springer International Publishing, pp 837-842.

[8] Đomlija P., Bočić N., Mihalić Arbanas S. (2017) Identification of Geomorphological Units and Hazardous Processes in the Vinodol Valley, Proceedings of the 2nd Regional Symposium on Landslides in the Adriatic- 
Balkan Region (Abolmasov, B.; Marjanović, M.; Đurić, U. eds). Belgrade: University of Belgrade, Faculty of Mining and Geology, pp 109-116

[9] Đomlija P. (2018) Identification and Classification of Landslides and Erosion by Visual Interpretation of Digital Elevation Model of Vinodol Valley, Dissertation, Faculty of Mining, geology and petroleum; University of Zagreb (in Croatian).

[10] Vivoda Prodan M. (2016) The Influence of Weathering Process on Residual Shear Strength of Fine Grained Lithological Flysch Components, Doctoral dissertation, Faculty of Civil Engineering, University of Rijeka. (in Croatian)

[11] Vivoda Prodan M., Mileusnić M., Mihalić Arbanas S., Arbanas Ž. (2017) Influence of Weathering Processes on the Shear Strength of Siltstones from a Flysch Rock Mass along the Northern Adriatic Coast of Croatia. (Bulletin of engineering geology and the environment. 76 (2017), 2; 695-711.

[12] Peranić J, Arbanas Ž, Cuomo S, Maček M (2018) Soil-Water Characteristic Curve of Residual Soil from a Flysch Rock Mass, Geofluids, Article ID 6297819, 2018:15 pages. doi:10.1155/2018/6297819

[13] Peranić J. (2019) Importance of Geotechnical Cross-Section Unsaturated Zone for Landslide Occurrence in Flysch Deposits, Doctoral dissertation, Faculty of civil engineering, University of Rijeka, https://urn.nsk.hr/ urn:nbn:hr:157:773572

[14] Vračević D. (2019) Examining Mechanical Properties of Limestone, Final paper, Faculty of civil engineering, Rijeka.

[15] Hodanić M. (2016) Comparison of the UCS Values Gained through Different Laboratory Testing, Final paper, Faculty of civil engineering, Rijeka.

[16] Cargill J.S., Shakoor A. (1990) Evaluation of Empirical Methods for Measuring the Uniaxial Strength of Rock. Int. J. Rock Mech. Min. Sci., 27: 495-503.

[17] Sachpazis C. I. (1990) Correlating Schmidt Hardness with Compressive Strength and Young's Modulus of Carbonate Rocks, Bulletin of the International Association of Engineering Geology, 42 (1990), pp. 75- 84, http://dx.doi.org/10.1007/BF02592622

[18] Yurdakul M., Ceylan H., Akdas H. (2011). A Predictive Model for Uniaxial Compressive Strength of Carbonate Rocks from Schmidt Hardness. Proc. 45th US Rock Mechanics Geomechanics Symposium held in San Francisco, CA, June 26-29. ARMA 11-533.

[19] Nazir R., Momeni E., Jahed Armaghani D., Mohd Amin. M. F. (2013) Prediction of Unconfined Compressive Strength of Limestone Rock Samples Using L-Type Schmidt Hammer. Electronic Journal of Geotechnical Engineering. 18 (I): 1767-1775.

[20] Romana, M. (1999) Correlation Between Uniaxial Compressive and Point Load (Franklin Test) Strengths for Different Rock Classes, $9^{\text {th }}$ ISRM Congress, Paris, pp. 673-676.

[21] Tsiambaos G., Sabatakakis N. (2004) Considerations on Strength of Intact Sedimentary Rocks. Engineering Geology, 72 (2004), pp. 261- 273, http:// dx.doi.org/10.1016/j.enggeo.2003.10.001 
[22] Tahir M., Mohammad N., Din F. (2011) Strength Parameters and Their Inter-Relationship for Limestone of Cherat and Kohat Areas of Khyber Pakhtunkhwa. Journal of Himalayan Earth Sciences. 44 (2): 45-51.

[23] Mihalić Arbanas S., Sečanj M., Bernat Gazibara S., Krkač, M., Begić, H., Džindo A., Zekan S., Arbanas Ž. (2017) Landslides in the Dinarides and Pannonian Basin - from the Largest Historical and Recent Landslides in Croatia to Catastrophic Landslides Caused by Cyclone Tamara (2014) in Bosnia and Herzegovina, Landslides, 14 (2017), 6; 1861-1876, doi:10.1007/s10346017-0880-1.

[24] Miller, R.P. (1965) Engineering Classification and Index Properties for Intact Rock, Dissertation, University of Illinois, USA, 1965.

[25] ISRM (1979) Suggested Methods for Determining the Uniaxial Compressive Strength and Deformability of Rock Materials, Int. J. Rock Mech. Min. Sci., 36: 279-289, Pergamon.

[26] Deere D.U., Miller R.P. (1966) Engineering Classification and Index Properties for Intact Rock. Air Force Weapons Lab. Tech. Report, AFWL-TR 65-116, Kirtland Base.

[27] ASTM (2000) Standard Testing Method for Determination of the Point Load Strength Index of Rock. Annual Book of ASTM standards, American Society of Testing Materials, Philadelphia ASTM 04.08 (D5731-02).

[28] ISRM (1985) Suggested Methods for Determining Point Load Strength, Int. J. Rock Mech. Min. Sci. \& Geomech. Abstr. Pergamon Press, Great Britain, Vol. 22:53-60.

[29] ASTM (2008) Standard Practices for Preparing Rock Core as Cylindrical Test Specimens and Verifying Conformance to Dimensional and Shape Tolerances, ASTM International, SAD.

[30] Aydin A. (2015). ISRM Suggested Method for Determination of the Schmidt Hammer Rebound Hardness: Revised Version in The ISRM Suggested Methods for Rock Characterization, Testing and Monitoring: 2007-2014, R. Ulusay (ed.), DOI: 10.1007/978-3-319-07713-0, pp. 25-33.

[31] Aydin A., Basu A. (2005). The Schmidt Hammer in Rock Material Characterization. Eng Geol 2005; 81:1-14.

[32] Dobrilović I., Gulam V., Hrženjak P. (2010) Application of Index Testing Methods in Determining Mechanical Properties of Intact Rock Material, Rudarsko-geološko-naftni zbornik, 22, 63-71 p. (in Croatian).

[33] Garrido M.E., Hidalgo C., Preciado J.I. (2010). Prácticas de laboratorio geotecnia y cimientos I. Departamento de Ingeniería del Terreno. Universidad Politécnica de Valencia, Ref.:2010.418, Editorial UPV.

[34] Broch E., Franklin J. (1972) J. Rock Mech. Min. Sci. 9(6), 669-697.

[35] Galván M., Preciado J., Serón J. (2014). Correlation between the Point Load Index, Is(50), and the Resistance to Unconfined Compression in Limestone from the Comunidad Valenciana, Spain; Acta Geotechnica Slovenica, 2014/2, pp. 35-45. 
[36] Bieniawski Z.T. (1975). Point Load Test in Geotechnical Practice. Engineering Geology; 9(1):1-11

[37] Akram M., Bakar M. Z. A. (2007). Correlation between Uniaxial Compressive Strength and Point Load Index for Salt-Range Rocks. Pak. J. Engg. \& Sci. 1. 